$\begin{gathered}\text { Науковий вісник НЛтУ України } \\ \text { Scientific Bulletin of UNFU } \\ \text { https://nv.nltu.edu.ua }\end{gathered}$
$\begin{aligned} & \text { https://doi.org/10.15421/40281010 } \\ & \text { Article received 27.10.2018 p. } \\ & \text { Article accepted 29.11.2018 p. } \\ & \text { УДк 630*5:582.632.1(477.51) }\end{aligned}$
ISSN 2594-7836 (print)
$\begin{array}{r}\text { Correspondence author } \\ \text { O. M. Tyschenko } \\ \text { o.tyschenko@ukr.net }\end{array}$

О. М. Тищенко

Наџіональний університет біоресурсів і природокористування Украйни, м. Київ, Україна

\title{
ЛІСІВНИЧО-ТАКСАЦІЙНА ХАРАКТЕРИСТИКА БЕРЕЗОВИХ ДЕРЕВОСТАНІВ ЧЕРНІГІВСЬКОГО ПОЛІССЯ
}

\begin{abstract}
Проаналізовано лісівничо-таксаційні особливості розподілу площ березових деревостанів Чернігівського Полісся за віком, типами лісорослинних умов, повнотою, бонітетом та походженням на підставі повидільної бази даних таксаційної характеристики лісів ВО "Укрдержліспроект". Розраховано середні таксаційні показники березняків цього регіону: вік, відносну повноту, запас, зміну запасу, бонітет, висоту, діаметр, частку участі берези у складі. Лісові насадження Чернігівського Полісся становлять 713,4 тис. га, 3 яких 395,9 тис. га підпорядковані обласному управлінню лісового та мисливського господарства. Площа вкритих лісовою рослинністю земель - 355,8 тис. га, середня лісистість території сягає близько $25,1 \%$. У регіоні досліджень склалися оптимальні кліматичні, грунтові, гідрологічні умови для вирощування березових насаджень, які займають площу 36,8 тис. га (10,3 \%) та становлять найбільшу частку серед м'яколистяних порід. За бонітетною шкалою переважають високопродуктивні насадження I та II класу бонітету. Характерними та домінантними типами лісорослинних умов для березняків $\epsilon$ свіжі та вологі субори, вологі сугруди $\left(\mathrm{B}_{2}, \mathrm{~B}_{3}, \mathrm{C}_{3}\right)$. Переважають середньовікові березові деревостани, вони становлять $51,3 \%$, стиглі та перестиглі - 28,3\%. Домінуюча відносна повнота насаджень знаходиться в діапазоні від 0,7 до 0,9. За походженням переважають вегетативні порослеві - 59,2 \%, насіннєві штучні - 29,2 \% та насіннєві природні $11,6 \%$. За коефіцієнтом участі берези у складі деревостанів більшість становлять насадження 8 та 7 одиниць. Зібрані дані буде використано для проведення подальших досліджень форми стовбурів та сортиментної структури березових деревостанів Чернігівського Полісся.
\end{abstract}

Ключові слова: березові деревостани; середні таксаційні показники; розподіл площ; сортиментна структура.

Вступ. У сучасних умовах до точності оцінки лісових ресурсів ставляться високі вимоги. Без докладного обліку неможливе планування та раціональне ведення господарства, забезпечення його прибутковості на рівні підприємства. Важливим є розроблення та впровадження на регіональному рівні нових, більш деталізованих нормативів та методів таксації лісосік для визначення реальних біометричних параметрів стовбурів та розроблення сортиментних таблиць для досліджуваного регіону.

Ліси Чернігівського Полісся, згідно з фізико-географічним районуванням, відносять до північно-східної частини України. За даними С. А. Генсірука (Hensiruk, 2002), регіон входить до Києво-Чернігівського Поліського округу й охоплює два лісогосподарські райониПридніпровсько-Поліський та Східнополіський.

У лісовому фонді Чернігівського Полісся провідне місце займають березові деревостани, переважно з берези повислої (Betula pendula Roth.) та берези пухнастої (Betula pubescens L.), які сформувалися замість соснових та дубово-соснових лісів. Вони досить поширені, але великих масивів не утворюють, трапляються у поєднанні з лісами, на місці яких утворилися. Для них характерний значний домішок у складі сосни звичайної, рідше дуба звичайного, осики тощо (Andryenko, 1983).

За дослідженнями С. А. Генсірука та М. С. Нижника, береза повисла є важливим об'єктом ведення лісово- го господарства в Україні як в еколого-лісівничому, так i в ресурсному значенні (Hensiruk, 1995). За літературними даними (Lakyda \& Matushevych, 2006), цю деревну породу вважають незамінною завдяки іiі швидкорослості, інтенсивному синтезу органічної речовини, киснепродуктивності, значній концентрації вуглецю у компонентах фітомаси.

Мета дослідження - встановити та проаналізувати особливості лісівничо-таксаційної структури березових лісостанів Чернігівського Полісся для проведення подальших досліджень форми стовбурів та сортиментної структури деревостанів.

Матеріали та методика дослідження. Для аналізу лісового фонду регіону досліджень використано повидільну базу даних таксаційної характеристики лісів виробничого об'єднання "Укрдержліспроект" лісового фонду України станом на 01.01.2011 р. Вибірка складається 312447 виділів десяти лісогосподарських підприємств Чернігівського обласного управління лісового та мисливського господарства, загальна площа яких становить 32,1 тис. га та запасом 5757,126 тис. м ${ }^{3}$.

Обробку вихідних даних здійснено на ПК за допомогою процесора MS Excel, використано наявні математичні та статистичні функції й інструменти побудови діаграм. У роботі застосовували загальновідомі в лісовій таксації і біометрії методи обгрунтування узагальне-

\section{Інформація про автора:}

Тищенко Олександр Миколайович, аспірант заочної форми. Email: o.tyschenko@ukr.net

Цитування за ДСтУ: Тищенко О. М. Лісівничо-таксаційна характеристика березових деревостанів Чернігівського полісся. Науковий вісник НЛТУ України. 2018, т. 28, № 10. С. 49-52.

Citation APA: Tyschenko, O. M. (2018). Silvicultural and taxational characteristics of Chernihiv Polissya birch forest stands. Scientific Bulletin of UNFU, 28(10), 49-52. https://doi.org/10.15421/40281010 
ної лісівничо-таксаційної характеристики лісів, зокрема розрахунок середніх показників деревостану, наприклад запасу на 1 га, бонітету тощо (Strochynskyi \& Kashpor, 2013).

Результати дослідження. Загальна площа земель лісового фонду Чернігівського Полісся становить 713,4 тис. га, 3 яких 395,9 тис. га підпорядковані обласному управлінню лісового та мисливського господарства. Площа вкритих лісовою рослинністю ділянок355,8 тис. га. За даними державного обліку лісів станом на 01.01.2011 p. (Dovidnyk lisovoho fondu Ukrainy, 2012), у Чернігівському Поліссі найбільшу площу займають насадження з перевагою у складі сосни звичайної $(60,6 \%)$, дуба звичайного $(15,9 \%)$, берези повислої (10,3\%) та вільхи клейкої (5,8 \%), а також 4,2 \% відведено насадженням інших деревних порід (рис. 1).

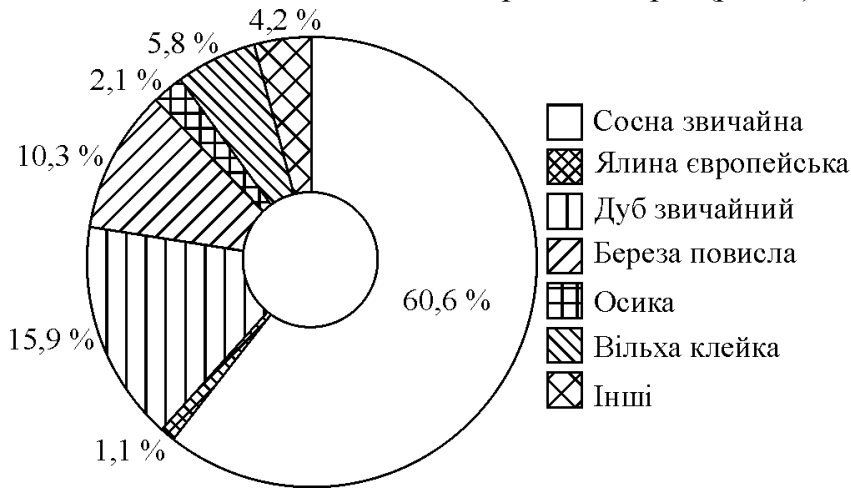

Рис. 1. Розподіл площі вкритих лісовою рослинністю лісових ділянок Чернігівського Полісся

Найменша частка $(2,1 \%)$ від загальної площі відведено осиковим насадженням лісогосподарських підприємств регіону досліджень.

Важливим таксаційним показником, який характеризує структуру деревостанів, є вік. Від його параметрів залежить призначення основних лісогосподарських заходів, обсяги ресурсного забезпечення держави високотоварною деревиною. Вікова структура березових деревостанів Чернігівського Полісся досить нерівномірна, зокрема основну частку займають середньовікові$51,3 \%$, стиглі та перестиглі насадження - 28,3\%, молодняки становлять $14,1 \%$. Середній вік насаджень становить 45 років. Докладніший аналіз середніх таксаційних показників за класами віку наведено в табл. 1.

Табл. 1. Середні таксаційні показники березових деревостанів Чернігівського Полісся за класами віку

\begin{tabular}{|c|c|c|c|c|c|c|}
\hline $\begin{array}{c}\text { Клас } \\
\text { віку }\end{array}$ & \begin{tabular}{|c|} 
Загаль- \\
на пло- \\
ща ви- \\
ділів, га
\end{tabular} & $\begin{array}{c}\mathrm{Ce-} \\
\text { редня } \\
\text { висо- } \\
\text { та, м } \\
\end{array}$ & \begin{tabular}{|c|} 
Серед- \\
ній ді- \\
аметр, \\
м \\
\end{tabular} & $\begin{array}{c}\text { Віднос- } \\
\text { на пов- } \\
\text { нота }\end{array}$ & $\begin{array}{c}\text { Запас дере- } \\
\text { востанів, } \\
\text { м }^{3} \text { ra }^{-1}\end{array}$ & $\begin{array}{l}\text { Запас, } \\
\text { тис. м }\end{array}$ \\
\hline I & 1330,8 & 4,3 & 4,8 & 0,69 & 25 & 33,135 \\
\hline II & 2306,8 & 9,8 & 11,8 & 0,75 & 74 & 171,286 \\
\hline III & 4694,9 & 13,2 & 15,5 & 0,78 & 110 & 514,849 \\
\hline IV & 5300,6 & 16,0 & 18,5 & 0,79 & 153 & 810,276 \\
\hline $\mathrm{V}$ & 6461,8 & 18,7 & 21,9 & 0,78 & 193 & 1244,453 \\
\hline VI & 2887 & 21,7 & 25,6 & 0,75 & 231 & 666,488 \\
\hline VII & 5474,3 & 23,7 & 28,6 & 0,72 & 250 & 1366,685 \\
\hline VIII & 3017,7 & 25,4 & 30,8 & 0,70 & 264 & 798,137 \\
\hline IX & 501,2 & 25,8 & 32,5 & 0,67 & 257 & 128,887 \\
\hline $\mathrm{Xi}>$ & 89,1 & 26,1 & 36,3 & 0,61 & 257 & 22,931 \\
\hline $\begin{array}{c}\text { Всьо- } \\
\text { го }\end{array}$ & 32064,2 & 18,5 & 22,6 &, 72 & 180 & 757,1 \\
\hline
\end{tabular}

Під час розрахунку даних табл. 1 запас на 1 га визначали як частку від загального запасу ділянок та їхні площі, решту показників знаходили як середнє зважене через площу ділянок. Наявні вікова структура та розподіл запасів березових деревостанів Чернігівського Полісся $\epsilon$ наслідком незадовільного вживання лісогосподарських заходів 30-50 років тому і не є оптимальними.

Розподіл площі насаджень з участю берези, за їі часткою в складі, зображено на рис. 2.

Площа, \%

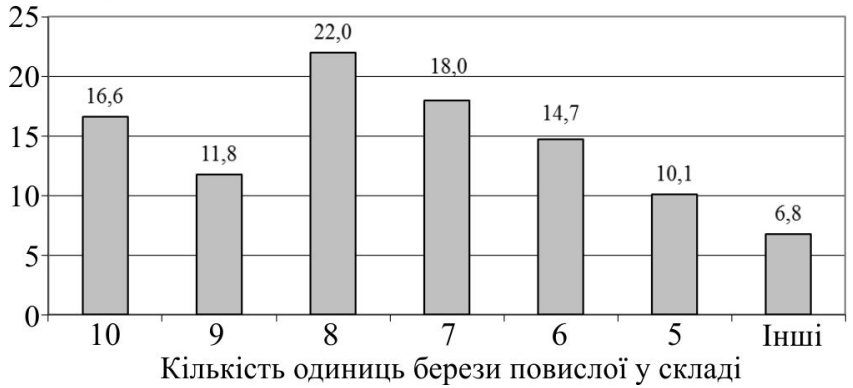

Рис. 2. Розподіл площі насаджень з участю берези за ії часткою в складі

Встановлено, що переважають березові насадження, які мають 7 та 8 одиниць у складі - 12,8 тис. га (40,0 \%). Чисті березняки зростають на площі 5,3 тис. га (16,6\%). Одним із показників продуктивності лісостанів $є$ клас бонітету. Розподіл площі та запасу березових деревостанів за продуктивністю наведено в табл. 2.

Табл. 2. Розподіл площі та запасу березових деревостанів за класами бонітету

\begin{tabular}{|c|c|c|c|c|}
\hline \multirow{2}{*}{$\begin{array}{c}\text { Клас боні- } \\
\text { тету }\end{array}$} & \multicolumn{2}{|c|}{ Площа } & \multicolumn{2}{c|}{ Запас } \\
\cline { 2 - 5 } & га & $\%$ & тис. $\mathrm{M}^{3}$ & $\mathrm{M}^{3} \cdot \mathrm{гa}^{-1}$ \\
\hline $\mathrm{I}^{\mathrm{b}} \mathrm{i}>$ & 3235,4 & 10,1 & 580,434 & 179 \\
\hline $\mathrm{I}^{\mathrm{a}}$ & 5110,5 & 15,9 & 959,074 & 188 \\
\hline $\mathrm{I}$ & 9776 & 30,5 & 1981,657 & 203 \\
\hline $\mathrm{II}$ & 11292,5 & 35,2 & 1938,302 & 172 \\
\hline $\mathrm{III}$ & 2163,7 & 6,7 & 263,373 & 122 \\
\hline $\mathrm{IV}$ & 448,1 & 1,4 & 31,956 & 71 \\
\hline $\mathrm{V} \mathrm{i}<$ & 38,0 & 0,1 & 2,330 & 61 \\
\hline Всього & 32064,2 & 100 & 5757,126 & 180 \\
\hline
\end{tabular}

Найчастіше в умовах Чернігівського Полісся береза утворює високопродуктивні деревостани I та II класів бонітету - сукупна частка зайнятої площі становить $65,7 \%$, рідше $\mathrm{I}^{\mathrm{a}}-15,9 \%$, а I $\mathrm{I}^{\mathrm{b}} \mathrm{i}>$ в сукупності $10,1 \%$. Середньопродуктивні березові деревостани III класу бонітету займають лише 6,7 \% загальної площі, низькопродуктивні IV та V класів бонітету трапляються рідко $-1,5 \%$.

Розподіл площі березових деревостанів за відносною повнотою, від якої залежить низка показників (запас, видовий склад лісового біоценозу, маса підстилки та ін., зображено на рис. 3.

Площа, \%

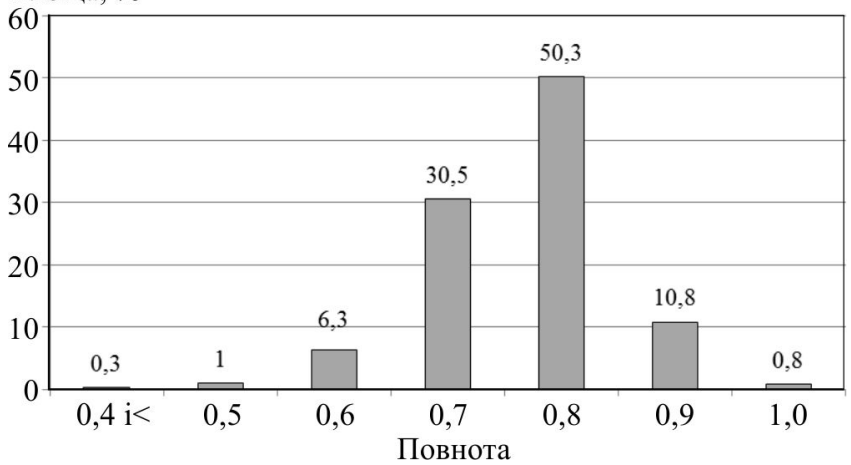

Рис. 3. Розподіл площі березових насаджень за повнотою

Дані (див. рис. 3) свідчать, що переважають високоповнотні насадження 3 повнотою 0,8 (50,3 \% від зайня- 
тої ними площі) та середньоповнотні 3 повнотою 0,7 $(30,5 \%)$. Середня відносна повнота насаджень дорівнює 0,76, що загалом, з погляду лісівництва, відповідає оптимальній (Svyrydenko \& Shvydenko, 1995).

Як і більшість деревних порід, береза повисла має здатність розмножуватися двома способами: насіннєвим і вегетативним. Встановлено, що за походженням у березових деревостанах Чернігівського Полісся переважають вегетативні порослеві (59,2 \%), насіннєві штучні становлять 29,2 \%, а насіннєві природні11,6\%. Середні таксаційні показники різних за походженням березових деревостанів наведено в табл. 3.

Табл. 3. Середні таксаційні показники різних за походженням березових деревостанів

\begin{tabular}{|c|c|c|c|c|c|c|c|}
\hline \multirow[b]{2}{*}{$\begin{array}{l}\text { Похо- } \\
\text { дження }\end{array}$} & \multirow[b]{2}{*}{ 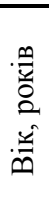 } & \multirow[b]{2}{*}{ 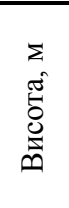 } & \multirow[b]{2}{*}{ 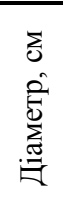 } & \multirow[b]{2}{*}{ 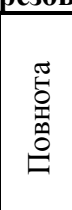 } & \multicolumn{2}{|c|}{ Запас, $\mathrm{m}^{3} \cdot r \mathrm{a}^{-1}$} & \multirow{2}{*}{ 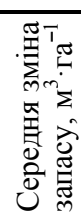 } \\
\hline & & & & & 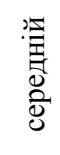 & $\begin{array}{l}\text { стиглих і } \\
\text { перестиг- } \\
\text { лих }\end{array}$ & \\
\hline Порослеві & 48 & 18,8 & 22,3 & 0,74 & 186 & 252 & 3,9 \\
\hline $\begin{array}{l}\text { Насіннєві } \\
\text { природні }\end{array}$ & 38 & 15,2 & 18,3 & 0,75 & 143 & 255 & 3,8 \\
\hline $\begin{array}{c}\text { Насіннєві } \\
\text { штучні }\end{array}$ & 42 & 17,4 & 20,5 & 0,78 & 171 & 254 & 4,1 \\
\hline
\end{tabular}

Порослеві та насіннєві деревостани відрізняються середнім віком та, як наслідок, середнім запасом, зміною запасу, середньою висотою та середнім діаметром. У стиглих та перестиглих деревостанах спостерігаємо майже однаковий середній запас. Перед розробкою лісотаксаційних нормативів, питання особливостей різних за походженням деревостанів потребує докладнішого дослідження та аналізу.

Аналіз розподілу площі березових деревостанів за типами лісорослинних умов наведено на рис. 4 .

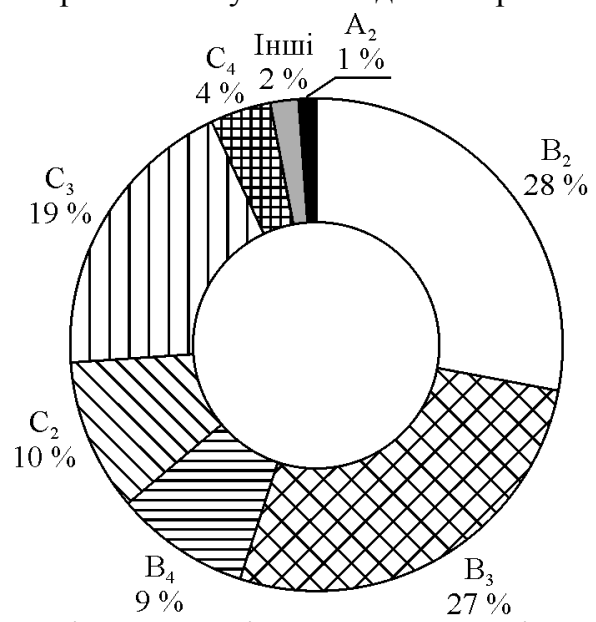

Рис. 4. Розподіл деревостанів берези за типами лісорослинних умов від зайнятої площі
За даними рис. 4, березові деревостани в регіоні дослідження зростають майже в усіх типах лісорослинних умов, окрім сухих сугрудків і мокрих грудів. Найбільше їх у свіжих суборах, вологих суборах, вологих сугрудах. Значну частку займають сирі субори та свіжі сугрудки. Рідше трапляються в сирих сугрудках.

\section{Висновки:}

1. Площа березових деревостанів у Чернігівському Поліссі становить 36,8 тис. га, або 10,3 \% площі вкритих лісовою рослинністю земель.

2. Розподіл площі за групами віку досить нерівномірний, основну частку займають середньовікові- $51,3 \%$, стиглі та перестиглі насадження - 28,3 \%, молодняки становлять $14,1 \%$. За коефіцієнтом участі берези у складі більшість становлять насадження 8 та 7 одиниць.

3. Березові ліси Чернігівського Полісся представлені переважно високопродуктивними насадженнями I та II класу бонітетів $(65,7 \%)$, а частка низькопродуктивних IV класу i $<$ становить лише 1,5\%. Площа насаджень насіннєвого походження становить $40,8 \%$, а вегетативного - $59,2 \%$. Основна частка $(80,8 \%)$ березових насаджень має відносну повноту від 0,7 до 0,8 .

4. Насадження берези повислої зростають переважно у всіх типах лісорослинних умов. Найбільше їх у свіжих та вологих суборах (55\%), вологих сугрудах (19\%).

5. Середні таксаційні показники березових деревостанів Чернігівського Полісся: вік - 45 років, діаметр 22,6 см, висота - 18,5 м, відносна повнота - 0,76, запас на 1 га - $176 \mathrm{~m}^{3}$, середній бонітет - I,2. Ці показники свідчать, що в регіоні досліджень переважають високобонітетні, середньовікові та середньоповнотні деревостани.

\section{Перелік використаних джерел}

Andryenko, T. L. (1983). Rastytelniy mir Ukrainskogo Polesiya v aspekte ego ohrany. Kyiv: Nauk. dumka, 216 p. [In Ukrainian].

Dovidnyk lisovoho fondu Ukrainy. (2012). [Guide Forest of Ukraine according to the materials of the state forest inventory as at 01.01.2011]. Irpin: VO "Ukrderzhlisproekt", 130 p. [In Ukrainian].

Hensiruk, S. A. (2002). Lisy Ukrainy. Lviv: Nauk. tov. im. Shevchenka, Ukr. derzh. lisotekhn. univer, 496 p. [In Ukrainian].

Hensiruk, S. A. (1995). Geografia lisovih resursiv Ukrainy. Lviv: Svit, Ukr. derzh. lisotekhn. univer, 241 p. [In Ukrainian].

Lakyda, P. I. \& Matushevych, L. M. (2006). Fitomasa berezovyh lisostaniv Ukrainskogo Polissya: monohrafiia. Kyiv: NNC IAE, 228 p. [In Ukrainian].

Strochynskyi, A. A. \& Kashpor, S. M. (2013). Normatyvno-informatsiinyi dovidnyk z lisovoi takastsii. Dovidnykove vydannia. Kyiv: Derzhavnyi komitet lisovoho hospodarstva Ukrainy. 283 p. [In Ukrainian].

Svyrydenko, V. I., \& Shvydenko, A. I. (1995). Lisivnytstvo. Kyiv: Silhospos-vita, 364 p. [In Ukrainian].

А. Н. Тищенко

Национальный университет биоресурсов и природопользования Украины, г. Киев, Украина

\section{ЛЕСОВОДСТВЕННО-ТАКСАЦИОННАЯ ХАРАКТЕРИСТИКА БЕРЕЗОВЫХ ДРЕВОСТОЕВ ЧЕРНИГОВСКОГО ПОЛЕСЬЯ}

Проанализированы лесоводственно-таксационные особенности распределения площадей березовых древостоев Черниговского Полесья по возрасту, типу лесорастительных условий, полноте, бонитету и происхождению на основе повыдельной базы данных ПО "Укргослеспроект". Рассчитаны средние таксационные показатели березняков этого региона: возраст, относительная полнота, запас, изменение запаса, бонитет, высота, диаметр, долевое участие в запасе березы. Лесные насаждения Черниговского Полесья составляют 713,4 тыс. га, из которых 395,9 тыс. га подчинены областному управлению лесного и охотничьего хозяйства. Площадь покрытых лесной растительностью земель - 355,8 тыс. га, средняя лесистость территории составляет $25,1 \%$. В регионе исследований сложились оптимальные климатические, грунтовые, гидрологические условия для выращивания березовых насаждений, которые занимают площадь 36,8 \% тыс. га (10,3\%) и составляют наиболь- 
шую часть среди мягколиственных пород. По бонитетной шкале преобладают высокопродуктивные насаждения I и II класса бонитета. Характерными и доминантными типами лесорастительных условий для березняков являются свежие и влажные суборы, влажные сугруды (В2, В3, С3). Преобладают средневековые березовые древостои, они составляют 51,3 \%, спелые и перестойные $-28,3 \%$. Доминирующая относительная полнота насаждений находится в диапазоне от 0,7 до 0,9 . По происхождению преобладают вегетативные порослевые - 59,2\%, семенные искусственные - 29,2\% и семенные природные $11,6 \%$. По коэффициенту участия березы в составе древостоев большинство составляют насаждения 8 и 7 единиц. Собранные данные будут использованы для проведения дальнейших исследований формы стволов и сортиментной структуры березовых древостоев Черниговского Полесья.

Ключевые слова: березовые древостои; средние таксационные показатели; распределение площадей; сортиментная структура.

O. M. Tyschenko

National University of Life and Environmental Sciences of Ukraine, Kyiv, Ukraine

\section{SILVICULTURAL AND TAXATIONAL CHARACTERISTICS} OF CHERNIHIV POLISSYA BIRCH FOREST STANDS

Silvicultural and taxation distribution features of birch stands area of Chernihiv Polissya were analyzed according to age, forest growth conditions types, density, productivity index of forest stands and origin on the basis of enhanced database of forests taxation characteristics by Ukrderzhlisproekt Production Association. The average taxation indexes of birch stands of the region calculated are as follows: age, relative density, stock, stock changes, productivity index of forest stands, height, diameter, birch part in the composition. Chernihiv Polissya forest stands constitute 713.4 thousand ha, of which 395.9 thousand ha are subordinated to the regional forest and hunting management. The forested area is 355.8 thousand ha; the average forest cover is about $25.1 \%$. In the research region optimal climatic, soil, and hydrological conditions were established for the birch plantations cultivation. These plantations occupy an area of 36.8 thousand ha $(10.3 \%)$ and constitute the largest portion of softwood tree species. According to productivity index of forest stands scale, the high-yield forest stands of the $1^{\text {st }}$ and the $2^{\text {nd }}$ bonitet classes predominate. Typical and dominant forest site types for the birch stands are fresh and wet ones $\left(\mathrm{B}_{2}, \mathrm{~B}_{3}, \mathrm{C}_{3}\right)$. Medieval birch stands are dominant; they make up $51.3 \%$, ripe and overmature stands $-28.3 \%$. The dominant relative stands density is in the range of 0.7 to 0.9 . By origin vegetative and sprout forest stands predominate $59.2 \%$, seedling artificial forest stands are $29.2 \%$ and seedling natural forest stands make up $11.6 \%$. According to the birch portion coefficient in the forest stand composition plantations of 8 and 7 units are majority. The collected data will be used for the further research conducting of stem form and assortment structure of Chernihiv Polissya birch stands.

Keywords: birch forest stands; average taxation indexes; area distribution; assortment structure. 